\title{
Mining and Indigenous Peoples of the North: Assessment and Development Prospects
}

\author{
Evdokia Burtseva ${ }^{1, *}$, Anatolii Sleptsov ${ }^{2, *}$, Anna Bysyina ${ }^{3}$, Alla Fedorova ${ }^{4}$ and \\ Gavril Dyachkovskii 4 \\ 1 Institute of Finances and Economics, M.K. Ammosov North-Eastern Federal University, \\ 677000 Yakutsk, Russia \\ 2 Faculty of Law, M.K. Ammosov North-Eastern Federal University, 677000 Yakutsk, Russia \\ 3 Sector for Research of Human Potential and Territorial Development of the State Autonomous Agency \\ "Centre for Strategic Studies", 677000 Yakutsk, Russia; ian.89@mail.ru \\ 4 Laboratory of the Electronic Cartographic Systems, Institute of Natural Sciences, M.K. Ammosov \\ North-Eastern Federal University, 677000 Yakutsk, Russia; fedas78@mail.ru (A.F.); \\ gavril_egorovich@mail.ru (G.D.) \\ * Correspondence: burtseva1999@mail.ru (E.B.); uyandi@mail.ru (A.S.)
}

Received: 27 June 2020; Accepted: 7 August 2020; Published: 14 August 2020

check for updates

\begin{abstract}
The main industry in the Republic of Sakha (Yakutia) is the mining industry, which will continue to expand in the future. Already today there are quite a lot of investment projects for the development of minerals in the Arctic, North-West and South Yakutia, which will be implemented in the territories of indigenous minorities of the North. Indigenous Evens, Evenks, Yukaghirs make up $4.2 \%$ of the total population of the republic and are characterized by low genetic diversity, which can lead to negative consequences in relation to their health status when exposed to technogenic pollution. Purpose of the study: assessment of the state of life of indigenous minorities of the North in the Republic of Sakha (Yakutia) under the conditions of a new stage of industrial development of territories of traditional nature management. The planned increasing industrial development of territories of traditional nature management can cause large-scale disturbances of the earth's surface, depletion of biological resources, environmental pollution, which will ultimately lead to deterioration in the quality of life of the population. In order to take measures to prevent and reduce the negative impacts of industrial development of the territories of residence and traditional activities of indigenous minorities of the North, when implementing new projects, the expert commission recommends concluding a trilateral agreement on cooperation and financing of specific programs between industrial companies, government bodies of the Republic of Sakha (Yakutia) and authorized representatives of indigenous minorities of the North. Research area-the position of indigenous minorities of the North in the conditions of industrial development of the North, Siberia and the Far East. This study looks at the impact of industrial development on the natural environment and the traditional way of life of indigenous population. Compensation for damage to the nomadic tribal communities of reindeer herders has taken place. Only about 250 thousand representatives of 40 indigenous peoples live in these regions, who are included in the official list of indigenous minorities of the North, Siberia and the Far East.
\end{abstract}

Keywords: indigenous minorities of the North; territories of traditional nature management; background industries; mining industry; ecosystem vulnerability; biological resources; zoning; ethnological expertise 


\section{Introduction}

By the time the Russians appeared, the vast territory of Yakutia (The Republic of Sakha, Eastern Siberia, Russia) was inhabited in the western and southern parts by Tungus (Evenks), in the north-eastern part by Lamuts (ancestors of modern Evens) and Yukaghirs, who led a nomadic and seminomadic lifestyle and were engaged in reindeer breeding, hunting, fishing and gathering wild plants [1]. These sectors of the economy today remain the leading ones for the life of the indigenous peoples.

The nature of Yakutia is distinguished by extreme climatic characteristics: the cold pole of the northern hemisphere is located here: the city of Verkhoyansk $-67.8^{\circ} \mathrm{C}$ (registered on 15 January 1885) [2], in the village of Oymyakon on 6 February $1933-67.7^{\circ} \mathrm{C}$ [3]. Permafrost is widespread almost throughout the republic; over $40 \%$ of the territory is located beyond the Arctic Circle [4]. On the territory of the republic, there are zones of the arctic desert, tundra and forest-tundra, taiga, while the nature of Yakutia is highly vulnerable to technogenic impacts.

Indigenous peoples have long inhabited the harsh Arctic and sub-Arctic territories, conducted their activities in accordance with and subject to customary law. The Sakha people and indigenous minorities of the North-Evens, Evenks, Dolgans, Yukaghirs, Chukchi, before joining Russia, themselves acted as the guarantor of their rights, establishing agreements on their basis. With the annexation of Eastern Siberia and the North to Russia in the 30s of the 17th century, the life of indigenous peoples radically changed: they lost their customary law, which was superseded by the state law of Russia [5].

The aim of the study is to assess the state of life of indigenous peoples of the Republic of Sakha (Yakutia) under the conditions of a new stage of industrial development of territories of traditional nature management.

For the management of indigenous peoples before the October revolution, the most significant legal act was the "Charter on the Management of Indigenes" (1822), in which tribal and neighboring communities were recognized as the basis of self-government and the subject of land tenure. The charter protected indigenes from assimilation, seizure of their lands, violation of their customs and traditions, cultural degeneration and extinction [6]. After the establishment of Soviet power, the way of life of the peoples of the North changed completely (ibid.):

- In the 20 s of the twentieth century self-government bodies were created (tribal councils, tribal meetings, executive committees). The land became the property of the Soviet state;

- In the 30s of the twentieth century collective reindeer herding farms have been organized, and national-territorial formations (national regions, autonomous districts) have been created. Under the conditions of a planned economy, the state carried out purposeful work to transfer the nomadic population to a settled way of life;

- In the late 1950s-early 1960s, there was a transition of farms to collective and state farm production.

- Until the 1970s, there was a decline in the number of farms engaged in reindeer husbandry: reindeer husbandry disappeared in Amginsky (1958), Verkhnevilyuisky (1957), Mirninsky (1976), Suntarsky (1956), Megino-Kangalassky (1967) city), Tattinsky (1963), Ust-Aldan (1956) regions of republic.

Reindeer husbandry is the main traditional type of management of indigenous peoples of the North and is regulated by the Law of the Republic of Sakha (Yakutia) "On northern domestic reindeer husbandry" [7]. According to many researchers [8-10], the market transformations of the 1990s led to the degradation of the traditional sectors of the economy of indigenous peoples of the North. During this period, in essence, the socio-economic sphere of the aboriginal peoples fell back 100 years ago [11]. In 2001-2005 both in Russia as a whole and in the places of residence of indigenous peoples, there has been some improvement in the state of the economy and the standard of living of the population, but the state of traditional industries continues to deteriorate [12]. So, for example, the number of reindeer in 1991 was 361,556 heads in the republic and in 2005 it was 144,476 heads, i.e., decreased by 2.5 times. 
During this period, there was a sharp decline in the living standards of indigenous peoples, which affected the deterioration of the health of the population [13]. To identify the dependence of the population's health on its well-being, the Institute of Health of the Academy of Sciences of the Republic of Sakha (Yakutia) in 2000-2001 conducted a comprehensive survey of the population of Oleneksky and Eveno-Bytantaysky regions of republic, where the indigenous minorities of the North live. The results of these surveys were compared with the regions of the Vilyui river basin, which were under the influence of the diamond mining industry. Studies have shown that in the Eveno-Bytantaysky region, the overall incidence of the population was 1.5 times higher than the incidence of the population in the ecologically unfavourable Vilyui region, in the Oleneksky region it is comparable to it. The main conclusion of the research: "the state of health of the population of indigenous peoples of the North is associated primarily with food, lifestyle, living conditions, the level of medical care, drug provision" (ibid.).

Currently, the study of the interaction of the indigenous minorities of the North and industrial companies is the most important part of the research field of the current situation of these peoples. Industrial development and its consequences are an important part of constructed social knowledge. It also has academic significance and is increasingly being used in the political struggle of the indigenous minorities of the North for their rights. Today, this struggle reflects the conflict between traditional and industrial use of natural resources; culture and traditions of indigenous peoples and the predatory use of natural resources and environmental pollution [14] Bogoslovskaya, 2015; [15] Burtseva, Petrova, 2017). The negative consequences of the industrial development of the Arctic lead to the destruction of the natural environment, unemployment, alcoholism, loss of traditional values and native languages of the aborigines, etc.

In recent years, quite a lot of scientific publications have appeared in the republic on the issues of the life of the indigenous peoples, the revival and development of traditional environmental management and the assessment of the impact of industrial facilities on the life of the indigenous peoples: on legal issues of ethnological expertise [16-18]; methodology for calculating losses of the indigenous minorities of the North [19,20]; assessment of the impact of industrial facilities on hunting resources [21,22]; ethnological expertise of projects [23-28]; compensation for damage to indigenous peoples from industrial development of territories [29,30], social security of indigenous peoples [31,32], the economy of traditional nature management [33-35], etc.

The Republic of Sakha (Yakutia), as one of the leading regions in terms of legal support related to the rights of indigenous peoples, is of particular interest to foreign researchers as well. Many works are devoted to the study of the problems of traditional nature management in the Arctic regions, in particular in the Republic of Sakha (Yakutia), among which the works of the authors can be noted: [36-41] and others.

All of them note that the experience of republic in terms of interaction between indigenous peoples and industrial enterprises, the effect of the Law on Ethnological Expertise, Republican programs to support traditional sectors of the economy, nomadic families, nomadic tribal communities, young reindeer herders, etc. serve as a positive example to other regions of indigenous people's residence, not only of Russia, but also of other Arctic countries.

In Russia an ethnological examination was carried out for the first time in 2002 by order of the Association of Indigenous Peoples of the Yamal-Nenets Autonomous District "Yamal to Descendants" by a team of authors from the Research Institute of Anthropology of Moscow State University, the Institute of Economic Planning and Forecasting of the Russian Academy of Sciences, Tula State University, the Moscow Regional Bar Association, Legal centre "Rodnik". The ethnological expertise concluded that the implementation of Gazprom's exploration program in the Obskaya and Tazovskaya bays is being carried out in violation of Russian legislation and poses a threat to the preservation of the indigenous peoples' habitat, and it also recommended that the license issued by Gazprom for the period of 2005 until the development of the program for providing socio-economic guarantees to the indigenous population in the event of negative consequences of the project implementation [42]. 
In 2010, a law of the Republic of Sakha (Yakutia) “On ethnological expertise in places of traditional residence and traditional economic activity of the indigenous minorities of the North of the Republic of Sakha (Yakutia)" was issued [43].

The ethnological expertise procedure consists of the following main stages:

1. Development of the document "Assessment of the impact on the ethnological environment (AIEE) in the places of residence and economic activity of the indigenous minorities of the North", the purpose of which is to identify potential impacts from the planned activities and predict possible consequences and risks for the ethnological environment for taking measures to prevent and reduce negative impacts. The development of the AIEE is carried out by tender; any legal associations (scientific, educational organizations, etc.) can participate in the tender. Research necessarily includes field, expeditionary desk work, as well as sociological research in national settlements, among reindeer herders, fishermen, pensioners, discussion at general meetings of the industrial project for the development of the territory and the preliminary results of sociological research.

2. Appointment of the expert commission of ethnological expertise as a result of a tender, which includes different scientists—biologists, economists, hydrologists, ichthyologists, sociologists, lawyers, etc.

3. Public hearings. The public hearings must be attended by representatives of industrial companies, the public, representatives of the indigenous minorities of the North, whose territory is subject to seizure for industrial development, the AIEE developers, representatives of scientific organizations, members of the expert commission, representatives of public organizations and government agencies and everyone who wants to participate in the public hearings.

4. Review of the submitted materials in the ethnological expertise is carried out taking into account all the comments and suggestions of the members of the expert commission, the results of public hearings. A special place is occupied by the attitude of indigenous peoples to the planned activities of industrial companies at the territories of traditional nature management (protocols and decisions of general meetings of tribal communities, national settlements, the results of sociological research). The expert commission as a result of ethnological expertise draws up a conclusion. The final decision on the permission or prohibition of the planned economic activities of industrial companies at the territories of traditional nature management is made by the Government of the Republic of Sakha (Yakutia).

\section{Materials and Methods}

The following materials were used:

- Research work "Comprehensive assessment of the impact of climate change and industrial development of the Arctic on the life of the indigenous population of the Nizhnekolymsky region of Yakutia", 2016;

- Research work "Assessment, main trends of the natural and socio-economic state, human potential of the Arctic economic zone of the Republic of Sakha (Yakutia)". State contract No. 5328 of NEFU.

- Scheme for the integrated development of productive forces, transport and energy in Yakutia until 2020" [44];

- Strategy of socio-economic development of the Republic of Sakha (Yakutia) until 2030 with the definition of a target vision until 2050 [45];

- Investment project "Integrated development of South Yakutia" [46];

- Materials of expeditionary work in Ust-Yansky (2018) and Anabarsky regions (2018) of Yakutia.

The general methodology of interdisciplinary research is represented by a complexity of methodological approaches: legal, historical and geographical, economic, analytical and synthetic, statistical, the scoring of the state of objects. The conceptual idea of this study is based on the analysis 
of the position of the indigenous peoples of the North and their interaction with industrial companies from the standpoint of legal anthropology within the framework of the methodology of legal pluralism which Vanderlinden [47], S. Moore, [48] and J. Griffith [49] considered as the coexistence of two or more legal systems, when human behavior, as defined by J. Griffiths, corresponds to more than one legal order. Another methodological basis of this study is the approach, developed by symbolic anthropology [50], when the analysis of the culture of the aborigines is not an experimental science in search of patterns, but the science of interpretation in search of meanings. This approach makes it possible to rely on scientific research, taking into account a wide range of rights and interests of the parties-the indigenous peoples of the North, industrial companies and authorities. Methodologically, the study of the interaction of indigenous minorities and industrial companies is also based on the statement about the relativity of boundaries between these groups and the role of these boundaries in the construction of old and new identities. F. Bart [51] presents an example of considering the "autochthonous model" through the analysis of the main value orientations that exist in the studied society.

To identify the connection of the studied objects with certain factors, their ranking along any axes of factors is widely used in various branches of science. Scoring was used especially widely in geographical, economic and social studies in the 1960s and 1970s. For example, in the geographical sciences, rating scales have been widely used for a comprehensive assessment of natural resources [52,53], zoning [54,55], etc. The zoning of the North was done by the Canadian economist and geographer L.E. Amlen [56], who gives a scoring of the "northernness" according to 10 physical and economic-geographical features and identifies three zones: Middle, Far, Far North. Since the 1990s, interest in the complex assessment of objects using point scales has increased again due to the need to solve various practical problems of a strategic, economic, environmental and social nature.

In the article, to assess the vulnerability of natural complexes to technogenic impacts, as well as to assess the incidence of indigenous peoples' tuberculosis, a universal quantitative indicator-the percentage of a feature in the estimated system of parameters, recommended by Burtseva E.I. [57] is used. This is the factor intensity index (FII), which is a deviation from the average state of an object in relative terms. The essence of the methodological approach is to bring indicators with different units of measurement into a single quantitatively comparable system using this index, which is determined by the formula:

$$
\mathrm{FTI}_{i}=\frac{a_{i}}{M}
$$

where: $a_{i}$-absolute value of the $i$-th indicator; $M$ is the absolute average value of a set of indicators

To compensate for the losses of the indigenous minorities of the North, Siberia and the Far East, in 2009, a methodology was developed for calculating the amount of losses caused to associations of these peoples [58]. However, the application of the document in specific projects of the assessment of the impact on the ethnological environment (AIEE) raised many controversial issues, and some of its provisions were not acceptable for calculating damage [24]. Potravny I.M., Gassiy V.V., Chernogradsky V.N., A.V. Postnikov [25], on the basis of studies carried out in the territories of compact residence of indigenous peoples in the Arctic zone of the republic (using the example of the activities of the Almazy Anabara group of companies), propose mechanisms for public-private partnership between authorities, business and the indigenous population for the purpose of socio-economic development arctic settlements.

\section{Results}

\subsection{The Modern Socio-Economic Situation of the Indigenous Minorities of the North}

According to the 2010 census, the number of indigenous minorities of the North in the republic is 39,936 people, including 36,079 people-Evenks and Evens; their share in the republic is $90.3 \%$, Dolgans, Chukchi and Yukagirs-9.7\%. Table 1 shows the ethnic composition of the indigenous population for 1970-2010. 
Table 1. National composition of the Indigenous Peoples' Population for 1970-2010.

\begin{tabular}{ccccccc}
\hline Nationality & $\mathbf{1 9 7 0}$ & $\mathbf{1 9 7 9}$ & $\mathbf{1 9 8 9}$ & $\mathbf{2 0 0 2}$ & $\mathbf{2 0 1 0}$ & $\begin{array}{c}\text { Increase in Comparison } \\
\text { With 1970, Times }\end{array}$ \\
\hline Evenki & 9097 & 11,584 & 14,428 & 18,232 & 21,008 & 2.3 \\
Evens & 6471 & 5763 & 8668 & 11,657 & 15,071 & 2.3 \\
Dolgans & 10 & 64 & 408 & 1272 & 1906 & 190.6 \\
Yukaghirs & 400 & 526 & 697 & 1097 & 1281 & 3.2 \\
Chukchi & 387 & 377 & 473 & 602 & 670 & 1.7 \\
Total & 16,365 & 18,314 & 24,674 & 32,860 & 39,936 & 2.4 \\
\hline \multicolumn{7}{c}{ Source: 2010 All-Russian Census Materials. }
\end{tabular}

The Evenks are settled throughout the territory of the republic; the Evens mainly live in the Arctic, North-East and Central Yakutia. The crisis state of most traditional types of economic activity has led to the aggravation of social problems. The average wages in the Arctic regions in 2013 amounted to 39.9 thousand rubles, which is $14.3 \%$ lower than the level prevailing in the republic ( 46.5 thousand rubles). The unemployment rate in most uluses exceeds the national average (7.4\%) [59]. The number of workers employed in reindeer husbandry is declining.

The Arctic and northern territories of the Republic of Sakha (Yakutia) are characterized by a continuing migration outflow of the population, a high level of morbidity and a decrease in the quality of educational and medical services. The most acute problems are under development of social infrastructure, dilapidation and accident rate of social facilities. To assess the dependence of the state of health on the social environment, statistical medical and demographic indicators for tuberculosis were analyzed using a quantitative indicator: the factor intensity index (IFI). A ranked series of tuberculosis prevalence among the population of the republic in ascending order of indicators: morbidity (newly diagnosed patients) and morbidity (registered patients), are presented in Tables 2 and 3 [31].

Table 2. The incidence of tuberculosis in the Republic of Sakha (Yakutia) for 2000-2010 (fragment).

\begin{tabular}{|c|c|c|c|}
\hline \multirow{2}{*}{ Regions of the RS(Ya) } & \multirow{2}{*}{ FTI * } & \multicolumn{2}{|c|}{ Incidence Per 100 Thousand People } \\
\hline & & Ranking Scale & Level \\
\hline Neryungrinsky & 0.04 & & \\
\hline Mirninsky & 0.07 & $<0.1$ & Low \\
\hline Bulunsky & 0.09 & & \\
\hline Srednekolymsky & 0.1 & & \\
\hline Lensky & 0.11 & $0.10-0.11$ & Decreased \\
\hline Aldansky & 0.12 & & \\
\hline Nizhnekolymsky & 0.13 & $0.12-0.14$ & Medium \\
\hline Zhigansky & 0.14 & & \\
\hline Oleneksky & 0.16 & & \\
\hline Ust-Yansky & 0.18 & $0.15-0.20$ & Increased \\
\hline Yakutsk & 0.19 & & \\
\hline Anabarsky & 0.21 & & \\
\hline Verkhoyansk & 0.22 & & \\
\hline Allankhovsky & 0.23 & $>0.20$ & High \\
\hline Abyysky & 0.27 & & \\
\hline Eveno-Bytantaysky & 0.32 & & \\
\hline
\end{tabular}


Table 3. Prevalence (registered) of tuberculosis in the Republic of Sakha (Yakutia) for 2000-2010 (fragment).

\begin{tabular}{cccc}
\hline Regions of RS (Ya) & FTI & \multicolumn{2}{c}{ Prevalence (Morbidity), Per 100 Thousand People } \\
\cline { 3 - 4 } & & Ranking Scale & Level \\
\hline Neryungrinsky & 0.05 & & \\
Bulunsky & 0.07 & 0.1 & Low \\
Mirninsky & 0.07 & $0.10-0.12$ & Decreased \\
Nyurbinsky & 0.11 & & \\
Aldansky & 0.11 & $0.12-0.15$ & Medium \\
Megino-Kangalassky & 0.12 & & Increased \\
Lensky & 0.12 & $0.16-0.20$ & \\
Srednekolymsky & 0.16 & & High \\
Zhigansky & 0.18 & & \\
Abyysky & 0.19 & & \\
Allaykhovsky & 0.2 & $>0.20$ & \\
Ust-Yansky & 0.21 & & \\
Yakutsk & 0.24 & & \\
Nizhnekolymsky & 0.26 & & \\
Oleneksky & 0.27 & & \\
Anabarsky & 0.41 & & \\
\hline
\end{tabular}

The high incidence of tuberculosis among the uluses of the republic is typical for five Arctic regions, where mainly indigenous peoples live: Anabarsky, Verkhoyansky, Allaikhovsky, Abyisky, Eveno-Bytantaysky. In terms of prevalence (Table 3), a high level of susceptibility is also characteristic of five Arctic regions: Allaikhovsky, Ust-Yansky, Nizhnekolymsky, Oleneksky, Anabarsky and for the city of Yakutsk.

Analysis of the prevalence of the population in the Republic of Sakha (Yakutia) with a socially significant infectious disease, tuberculosis, indicates a low level of the social environment in the Arctic uluses. For the city of Yakutsk, many factors affect the health of the population: a low level of improvement of the city, a deterioration of the environmental situation, an increase in the number of migrants from other countries and regions of Russia as well as intraregional unemployed migrants, which increase the load on the city infrastructure and increase the incidence of infectious diseases.

Official statistics do not take into account the morbidity of the population by ethnic composition, and it is not possible to assess the state of health according to the statistics of the indigenous peoples of the North in this period. It can only be assumed that the populations of the indigenous peoples of the North may be vulnerable to various external influences. According to the results of molecular genetic studies, the indigenous population of Yakutia (Evenks, Evens and Yakuts) living in the territories of the mining industry, according to the data of the paternal and maternal lines, as well as some autosomal loci, is characterized by a relatively low genetic diversity in comparison with other East Eurasian populations [60-63]. Small numbers, relative isolation and low genetic diversity can probably have a negative effect under the action of technogenic pollution, since the action of such exogenous factors can lead to a decrease in the natural adaptation mechanisms of the population.

As indicated above, reindeer herding is the main ethno-preserving industry of the indigenous peoples of the North. At present, the catastrophic reduction in the number of reindeer continues and in 2016 it amounted to 11,208 reindeer in the republic, i.e., it decreased by 33.9 times compared to 1981 (Table 4). If in 2001 the districts had livestock of more than 500 deer and there were 20, then in 2016 there were only 6 of them in the republic [30]. 
Table 4. Dynamics of the reindeer population in the Republic of Sakha (Yakutia) for 1981-2016.

\begin{tabular}{ccccccccc}
\hline & $\mathbf{1 9 8 1}$ & $\mathbf{1 9 9 1}$ & $\mathbf{2 0 0 1}$ & $\mathbf{2 0 1 0}$ & $\mathbf{2 0 1 3}$ & $\mathbf{2 0 1 4}$ & $\mathbf{2 0 1 5}$ & $\mathbf{2 0 1 6}$ \\
\hline Regions of the RS (Ya) & $\mathbf{3 8 0 , 0 2 8}$ & $\mathbf{3 6 1 , 5 5 6}$ & $\mathbf{1 5 6 , 2 3 7}$ & $\mathbf{2 0 0 , 8 2 5}$ & $\mathbf{1 9 1 , 0 7 0}$ & $\mathbf{1 0 , 3 4 3}$ & $\mathbf{1 0 , 3 4 3}$ & $\mathbf{1 1 , 2 0 8}$ \\
\hline Aldansky & 13,487 & 14,786 & 10,888 & 12,736 & 12,553 & 207 & 207 & 227 \\
Anabarsky & 26,188 & 24,758 & 16,214 & 16,284 & 13,800 & 501 & 501 & 1056 \\
Bulunsky & 40,757 & 30,021 & 10,732 & 17,608 & 15,821 & 654 & 654 & 514 \\
Verkhnekolymsky & 7838 & 8528 & 1321 & 1057 & 1122 & 82 & 82 & 67 \\
Verkhoyansky & 39,325 & 10,993 & 2492 & 6785 & 5036 & 59 & 59 & 69 \\
Vilyuisky & 955 & 540 & - & 37 & 180 & 0 & 0 & 4 \\
Gorny & 1556 & 974 & 333 & 248 & 296 & 0 & 0 & 5 \\
Zhigansky & 16,119 & 12,507 & 5580 & 6603 & 6322 & 107 & 107 & 101 \\
Kobiaisky & 15,300 & 19,957 & 15,983 & 16,188 & 10,103 & 414 & 414 & 538 \\
Momsky & 31,307 & 31,911 & 15,671 & 16,800 & 15,901 & 593 & 593 & 477 \\
Nizhnekolymsky & 36,435 & 35,138 & 13,003 & 18,669 & 19,911 & 3547 & 3547 & 3289 \\
Oymyakonsky & 17,758 & 18,316 & 9282 & 14,787 & 16,934 & 361 & 361 & 320 \\
Olekminsky & 3895 & 3714 & 3015 & 3822 & 4930 & 98 & 98 & 87 \\
Oleneksky & 24,036 & 20,047 & 5541 & 4794 & 5901 & 126 & 126 & 221 \\
Srednekolymsky & 8336 & 6923 & 2702 & 2846 & 3164 & 158 & 158 & 87 \\
Tomponsky & 21,903 & 23,896 & 12,760 & 19,547 & 12,007 & 353 & 353 & 491 \\
Ust-Maysky & 445 & 1093 & 877 & 715 & 507 & 24 & 24 & 6 \\
Ust-Yansky & 34,947 & 31,888 & 8357 & 14,657 & 19,217 & 2430 & 2430 & 2523 \\
Eveno-Bytantaysky & - & 26,329 & 9650 & 16,763 & 16,639 & 2430 & 2430 & 2523 \\
Neryungri & 9355 & 11,996 & 5435 & 6735 & 7438 & 433 & 433 & 933 \\
\hline
\end{tabular}

The main reasons for the decline in reindeer husbandry were: (a) the republic was not interested in the development of reindeer husbandry in the Yakut regions, where the local population has long been engaged in cattle breeding and horse breeding; (b) the indigenous peoples of the North were engaged in reindeer husbandry, which gradually assimilated; accordingly, there were no real reindeer herders who knew the methods of reindeer husbandry in the taiga zone [6].

\subsection{Natural and Economic Zoning of Traditional Nature Management of Small Peoples of the Republic of Sakha (Yakutia)}

I.I. Poiseev [9] distinguishes three forms of traditional nature management: tundra, mountain-taiga, alas-taiga, which are distinguished not by the direction of economic sectors but by the zonal feature of their distribution. All types of nature management, according to T.G. Runova et al. [64], depending on the natural resource base, recommend subdividing them into background and industrial-urban. On the territorial organization of nature management, E.I. Burtseva [57] on the territory of the Republic of Sakha (Yakutia) identifies eight ecological and economic regions of the 1st stage according to the background industries, and those, in turn, are divided into 19 regions of the 2nd stage according to industrial industries.

On the basis of the first stage ecological and economic regions, we have carried out the natural and economic zoning of the traditional nature management of the indigenous peoples of the Sakha Republic (Yakutia). The criterion for identifying natural and economic zones was the natural and ecological differentiation of the territory according to the nature of the distribution of vegetation, taking into account the controlling factor-the vulnerability of natural landscapes to technogenic impacts. Within the territory of the Republic of Sakha (Yakutia), eight natural and economic zones of traditional nature management have been identified according to the background industries (Figure 1). 


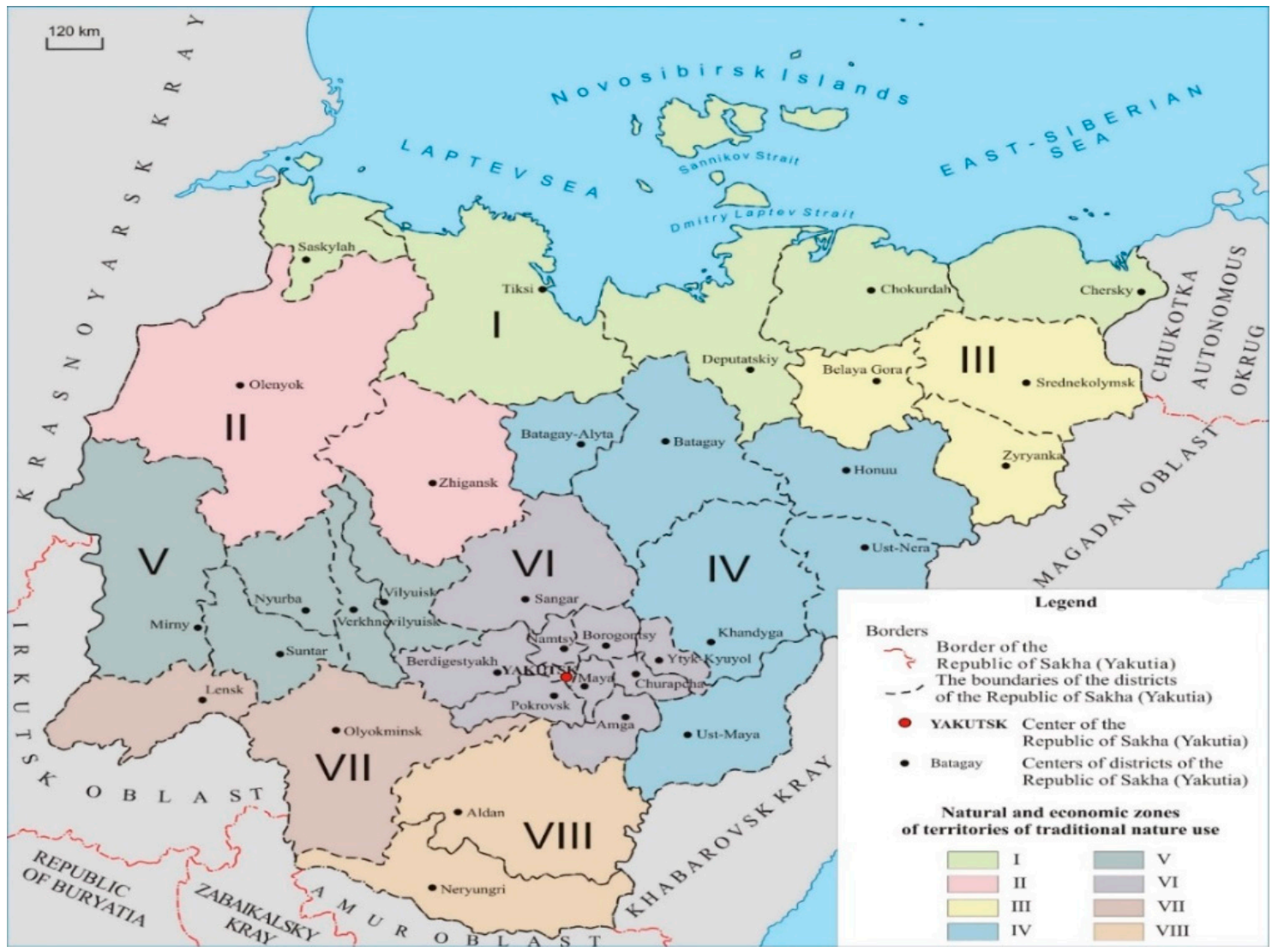

Figure 1. Natural and economic zones of territories of traditional nature management of RS (Ya). Note. I-Arctic tundra-hunting-reindeer breeding; II-North-Western northern taiga hunting and reindeer herding zone; III-North-Eastern lacustrine-taiga reindeer-cattle breeding; IV-North-Eastern mountain taiga reindeer-horse-breeding-cattle breeding; $\mathrm{V}$-Western middle taiga horse breeding and cattle breeding; VI-Central alas-middle taiga agricultural-horse-breeding-cattle breeding; VII-South-Western middle taiga agricultural and cattle breeding; VIII-South mountain-taiga agricultural, hunting and reindeer breeding.

Traditional types of nature management are developing in all natural and economic zones, but they are not leading in the economic structure of districts (uluses). At present, the indigenous peoples of the North live compactly in the Arctic tundra-hunting-reindeer-breeding, North-Western northern taiga commercial-reindeer-breeding and North-Eastern lake-taiga reindeer-herding-cattle-breeding zones, where the leading sectors of the economy are traditional types of nature management (Table 5). In other areas, the leading industries are mainly mining and agriculture. 
Table 5. Natural and economic zones of traditional nature use of the territory of the Republic of Sakha (Yakutia) and their specialization by branches of the economy.

\begin{tabular}{|c|c|c|}
\hline No. & $\begin{array}{l}\text { Natural and Economic Zones by } \\
\text { Background Industries }\end{array}$ & $\begin{array}{l}\text { Specialization of Territories by } \\
\text { Branches of the Economy }\end{array}$ \\
\hline 1 & Arctic tundra-hunting-reindeer breeding & $\begin{array}{l}\text { Reindeer husbandry, fishing, hunting, } \\
\text { local development of the diamond, tin } \\
\text { and gold mining industry }\end{array}$ \\
\hline 2 & $\begin{array}{l}\text { North-Western northern taiga hunting and } \\
\text { reindeer herding zone }\end{array}$ & $\begin{array}{l}\text { Reindeer husbandry; fishing, hunting, } \\
\text { local development of the diamond } \\
\text { mining industry }\end{array}$ \\
\hline 3 & $\begin{array}{l}\text { North-Eastern lacustrine-taiga } \\
\text { reindeer-cattle breeding }\end{array}$ & $\begin{array}{l}\text { Reindeer husbandry, fishing, local } \\
\text { development of the coal } \\
\text { mining industry }\end{array}$ \\
\hline 4 & $\begin{array}{l}\text { North-Eastern mountain taiga } \\
\text { reindeer-horse-breeding-cattle breeding }\end{array}$ & $\begin{array}{l}\text { Livestock, horse breeding, reindeer } \\
\text { breeding, fisheries, local development of } \\
\text { the gold mining industry }\end{array}$ \\
\hline 5 & $\begin{array}{l}\text { Western middle-taiga horse-breeding and } \\
\text { cattle breeding }\end{array}$ & $\begin{array}{l}\text { Gas, diamond mining, livestock, horse } \\
\text { breeding, hunting, poultry }\end{array}$ \\
\hline 6 & $\begin{array}{l}\text { Central alas-middle taiga } \\
\text { agricultural-horse-breeding-cattle breeding }\end{array}$ & $\begin{array}{l}\text { Livestock, horse breeding, reindeer } \\
\text { breeding, fisheries, agriculture, local } \\
\text { development of the coal } \\
\text { mining industry }\end{array}$ \\
\hline 7 & $\begin{array}{l}\text { South-Western middle taiga } \\
\text { reindeer-farming-cattle breeding }\end{array}$ & $\begin{array}{l}\text { Forestry, oil industry, hunting, livestock, } \\
\text { horse breeding, agriculture, reindeer } \\
\text { breeding }\end{array}$ \\
\hline 8 & $\begin{array}{l}\text { Southern mountain taiga land farming, } \\
\text { hunting and reindeer breeding }\end{array}$ & $\begin{array}{l}\text { Gold and coal mining, transport hub, } \\
\text { reindeer husbandry, } \\
\text { hunting, agriculture }\end{array}$ \\
\hline
\end{tabular}

Source: developed by the authors.

\subsection{Territories of Traditional Nature Management and Ethnological Expertise}

According to the legislation of the Russian Federation, territories of traditional nature management are specially protected territories, formed for the traditional use of natural resources by the indigenous peoples of the North, where the activities of industrial companies are limited and are possible only with the prior and informed consent of the aborigines [65]. In the context of industrial development of the natural resources of the Russian Federation, the creation of the territories of traditional nature management plays an important role in protecting the interests and rights of indigenous peoples: on the one hand, it is a deterrent factor in the destruction of their original habitat; on the other hand, it stimulates socio-economic development and an increase in the standard of living of associations of indigenous peoples [27]. As of 2018, 65 territories of traditional nature management with a total area of 1,690,000 hectares, more than half of the territory of the Republic of Sakha (Yakutia), were officially created (Table 6). There are 93 settlements in these territories.

In Russia, the only legislature enshrined at the regional level, independent assessment of the impact of industrial projects on the peoples of the North is the ethnological expertise of the Republic of Sakha (Yakutia). The concept of "ethnological expertise" is enshrined in the Federal Law "on guarantees of the rights of the indigenous minorities of the Russian Federation" [66] as "a scientific study of the impact of changes in the original habitat of indigenous peoples and the socio-cultural situation on the development of the ethnos", but the further development of this phenomenon in the federal legislation has not been received.

Over the 10 years of operation of the regional law of the Republic of Sakha (Yakutia) "On Ethnological Expertise", at the request of industrial companies, 15 expertises were conducted to assess the impact of industrial projects on the indigenous peoples of the North. Of these, the largest number of examinations was carried out at the territories of traditional nature management of South (seven investment projects) and Arctic (five investment projects) parts of the Republic of Sakha (Yakutia). 
Table 6. Indicators of territories of traditional nature management of local importance by natural and economic zones.

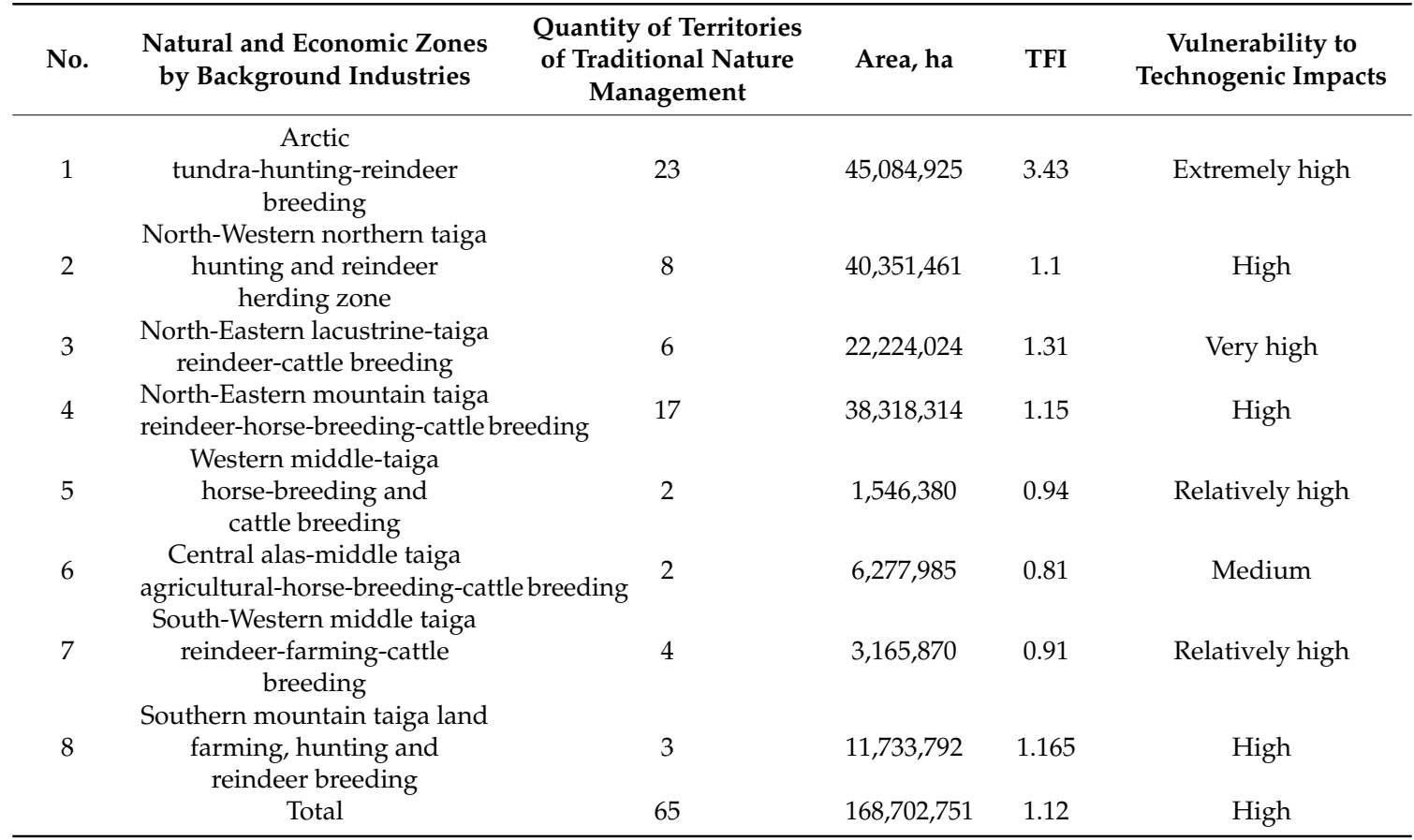

Source: Developed by the authors based on data from the Ministry for External Relations and Affairs of the Peoples of the Sakha Republic.

As a result of the ethnological examination procedure, new knowledge and scientific materials were obtained on the real socio-economic situation of the indigenous peoples of the North, which is extremely important in the absence of state statistics on the vital activity of the indigenous peoples of the North.

\subsection{Discussion}

According to the Strategy of Socio-Economic Development of the Republic until 2030 with a vision for 2050, one of the tasks of preserving and protecting the indigenous habitat of indigenous peoples is guaranteed compliance with the participation of industrial companies in the socio-economic development of territories inhabited by indigenous peoples. Currently, many researchers are raising the question of sharing the benefits from the development of mineral deposits at the territories of traditional nature management between industrialists and indigenous peoples [67-69].

The Arctic tundra-hunting-reindeer breeding zone includes five administrative districts (Allaikhovsky, Anabarsky, Bulunsky, Nizhnekolymsky, Ust-Yansky) and is a large reindeer herding region of the Republic of Sakha (Yakutia). The Arctic is of strategic value today from the point of view of national security and economic development of the state. These lands have rich mineral and raw material potential and are attractive for investment projects at the same time; they are distinguished by the fragility of ecosystems to anthropogenic impacts.

The state of the environment in the Arctic regions was assessed as satisfactory [57]. At present, diamonds and gold are mined in the Allaikhovsky and Bulunsky regions, tin is mined in Ust-Yansky, and the fishing industry is developed in the Allaikhovsky and Nizhnekolymsky regions. The development of the oil and gas industry is planned in the future.

In the ethnological expertise in 2015, materials were considered on complex geological and geophysical works for the search for oil and gas fields and their subsequent exploitation in the territories of Bulunsky and Anabarsky regions. Four tribal communities and two municipal unitary 
enterprises will be affected by the work on the territory of the Anabar region. On the territory of Bulunsky region-one municipal unitary enterprise and one individual enterprise.

The project received a positive opinion of the expert commission of ethnological expertise with a recommendation to correct it according the experts' comments during ethno-ecological monitoring.

The North-Western northern taiga hunting and reindeer herding zone includes the Oleneksky and Zhigansky districts. Economic specialization: reindeer husbandry, fur trade and fishing. The vulnerability of natural complexes to technogenic impacts is high. The state of the environment was assessed as favorable by a set of factors. [57]. At present, there is a diamond mining enterprise operating in the region (Almazy Anabara Open Joint Stock Company); in the near future there are plans to expand diamond production with the development of the following deposits:

- development of the Verkhne-Munskoye diamond deposit, 2016;

- development of an alluvial diamond deposit in the area "r. Big Kuonamka and Talakhtah ", 2016;

- mining operations in the area of Small Kuonamka with the Maspaki tributary for the development of diamond placers, 2016.

When considering the design documentation in the ethnological expertise, a lot of questions and comments from experts were raised by the project for the development of the Verkhne-Munskoye deposit. The plot of land for the construction and operation of the deposit is a zone of absolute peace in the natural republican reserve, "Beke". The expert commission in the first consideration of the materials recommended finalizing the assessment of the impact on the ethnological environment (AIEE). As a result of finalizing of the materials, the project received a positive opinion from the ethnological commission.

The North-Eastern lacustrine-taiga reindeer-herding-cattle-breeding zone includes three administrative regions: Abyisky, Verkhnekolymsky, Srednekolymsky. In the economic specialization of the region, the leading role belongs to animal husbandry and herd horse breeding, subordinate to hunting and fishing, as well as reindeer husbandry. Verkhnekolymsky ulus is an old mining region: here in 1936, with the development of a coal mine, the mining industry began to develop for the first time in republic. Currently, there are small mining enterprises in the region.

The state of the environment as a whole in the zone is satisfactory. However, the state of health of the population of the Kolyma regions of republic raises concerns: in Srednekolymsk there was an increased level (according to the integral assessment), in Verkhnekolymsk-an increased level of morbidity with malignant neoplasms, which, apparently, is associated not only with local but also transboundary pollution of the river. Kolyma is in the upper reaches and large-scale gold mining is carried out there. There are no new projects for industrial development of territories of traditional nature management.

The North-Eastern mountain taiga reindeer-horse-breeding-cattle breeding zone unites five administrative districts: Verkhoyansk, Momsky, Oymyakonsky, Ust-Maisky and Eveno-Bytantaysky. The zone represents a vast mountainous country and is distinguished by the severity of the climate, where the "paradoxes" of the nature of Yakutia are most pronounced: the Cold Pole of the Northern Hemisphere is located here, the steppes are widespread beyond the Arctic Circle and "clean" (northern version of mountain subalpine meadows) in the highlands. The vulnerability of natural complexes to technogenic impacts is relatively high.

Agriculture is represented by meat and dairy cattle breeding, reindeer breeding, herd horse breeding, hunting and animal husbandry. The zone is rich in mineral resources-gold, tin, antimony, lead, zinc, copper, mercury, tungsten, coking and thermal coals and is one of the oldest mining regions. The state of the environment as a whole in the zone is relatively satisfactory. In the ethnological expertise, one investment project was considered: Enrichment plant for processing gold-antimony ore of the Sentachan deposit, 2019. The land plot for the enrichment plant of the deposit is located at the Tabalakhsky territory of traditional nature management of local importance, Verkhoyansk region. 
The assessment of the impact on the ethnological environment (AIEE), submitted to the ethnological expertise as part of the project, after the documentation was finalized according to the comments of the experts, received a positive conclusion from the expert commission.

The Western middle taiga horse-breeding zone with the development of the diamond industry unites five administrative districts: Mirninsky, Vilyuisky, Verkhnevilyuisky, Nyurbinsky, Suntarsky, and is located mainly within the middle taiga; only the northern part of the territory is included in the northern taiga. The vulnerability of natural complexes to technogenic impacts is medium.

The western zone is characterized primarily as a diamond mining center. Today Yakutia is the world leader in diamond mining [70]. The zone is rich in mineral resources: diamonds, natural gas, oil, table salt, zeolites, medicinal mud, etc. During the development of the diamond industry until the 1980s, the state of the environment deteriorated sharply: in some areas, in particular along the tributaries of the river Vilyui-the rivers Irelyakh, Malaya Botuobiya, Daldyn, Markha—it was proposed to identify the status of an ecological disaster zone [71]. Since the 1980s, the company has undertaken a number of complex engineering and environmental tasks, thanks to which the environmental situation in the company's area of operation has become more stabilized [72].

In the ethnological expertise, two investment projects are considered:

1. Construction of exploration wells No. 581,582, 583 of the Tas-Yuryakhskoye oil and gas condensate field and winter roads to them. Business entity: Gazprom Geologorazvedka LLC, 2017. Two tribal communities fall under the influence of construction projects: Chuona tribal community and Botuobuya tribal community. The work at the first stage, in view of the numerous comments of the experts, is aimed at a fundamental revision and only after their correction received a positive opinion of the expert commission.

2. "Construction and operation of industrial facilities on the territory of the Central Block and the Kurungsky license area of the Srednebotuobinsky oil and gas condensate field". Business entity: Gazprom Geologorazvedka LLC, 2019. The facilities are located on the territory of Botuobuyinsky nasleg municipal district, Mirny district. The work received a positive opinion of the expert committee.

The Central alas-middle taiga agricultural-horse-breeding-cattle-breeding zone unites 10 administrative units. Production specialization-meat and dairy cattle breeding and herd horse breeding. Agriculture and fur trade are also developed here. Indigenous minorities ( 928 people) live in Kobyayskiy ulus on the territory of Lamynkha nasleg. Almost half of the working residents work in reindeer husbandry. Hunting and fishing resources are of great importance to the local population, which are an important source of income and food. The closed joint stock company "Prognoz", a Russian mining company, a subsidiary of the Canadian company SilverBearResources for silver mining at the Vertikalnoe deposit, operates on the territory of the municipal district. The project is currently under active capital construction. In 2017, the project received a positive opinion from the expert commission of ethnological expertise.

However, the population of the Lamynkhinsky nasleg is seriously concerned about: (a) the withdrawal of reindeer pastures in the calving and rutting territory, on which the reproduction of reindeer directly depends; (b) deterioration of the health of the population, in particular, reindeer herders who work in the area affected by the rotational village of CJSC "Prognoz". The quarry of the deposit belongs to the enterprises of the I hazard class, the dumps of rocks-to the objects of the II hazard class. In general, the mining and processing complex of the deposit can be classified as industrial facilities of the 1st hazard class.

As a result of public hearings, the population of this municipal district proposed to make additions to the trilateral agreement proposed by the expert commission:

- Carrying out ethno-ecological monitoring on the territory of economic activity of CJSC "Prognoz" every three years, which should include the state of biological resources; 
- Conducting medical and demographic monitoring in order to assess the state of health of the population every three years;

- To develop a program for the possible development of new lands for the further development of reindeer husbandry jointly with CJSC "Prognoz", since the shift camp with a population of 150 people is located on pastures of spring-autumn reindeer grazing — calving and rutting.

The Southwestern middle taiga reindeer-farming-cattle-breeding zone includes two administrative districts: Lensky and Olekminsky. The vulnerability of territories to man-made impacts is relatively low. Agricultural industries are represented by meat and dairy cattle breeding, potato growing, vegetable growing, fodder production and agriculture. The fur trade is quite widely developed. Reindeer husbandry has developed insignificantly. The zone is known in the republic as a major center of the logging and woodworking industries. The oil industry begins to develop here (Talakanskoye field). In the future, the region will turn into a large mining and industrial center for the oil and gold mining industry.

The environment state in the zone is relatively tense and the state of health of the population of both regions is attributed to an increased level of susceptibility, in terms of morbidity with malignant neoplasms: Lensky—high, Olekminsky—increased.

In the ethnological expertise, two investment projects are considered:

1. Construction of two single-circuit power transmission lines kV PS-15-PS-16. The basis for the design of the structure is the construction of power grid facilities as part of the external power supply scheme of the Eastern Siberia-Pacific Ocean pipeline system. The territory of tribal community "Kindigir" will fall under the influence of power lines. The main occupation of the indigenous peoples of the North is reindeer husbandry and hunting. The expert commission of ethnological expertise gave a lot of comments on the AIEE; after eliminating the comments, it made a positive conclusion on the documents provided.

2. Main gas pipeline "Power of Siberia". Stage 2.1-2.8. Olekminsky region, 2019 (for a description of the object, see below).

3. The Southern mountain-taiga agricultural-hunting-reindeer-breeding zone in historical development is the original habitat of the indigenous peoples of the North. Three settlements are registered on the territories of traditional nature management register: in the Aldansky region-"National district of Anama" and "Bellet national district"; in the Neryungrinsky region-the rural settlement "Iengrinsky Evenk national district".

On the territories of traditional nature management of South Yakutia, it is planned to build seven large investment objects:

1. Kankunskaya hydroelectric power plant for the period of research, construction and operation. Aldan, Neryungri districts, 2012 (the project is frozen)

2. Construction of two single-circuit kV transmission power lines PS-15-PS-16. Aldan district, 2015

3. Construction of a bridge over the river Aldan on the Aldan-Olekminsk-Lensk highway, Aldansky region, 2015

4. Trunk gas pipeline "Power of Siberia", Aldansky, Neryungri regions, 2015

5. Construction of an access railway to the Elga coal deposit from st. Ulak to st. Elga. Adjustment, 2018 6 and 7 (the name of investment projects and their description, see below)

On all the projects, the experts indicated quite a lot of comments; after correcting the comments, the materials of the assessment of the impact on the ethnological environment as part of the projects received a positive opinion of the expert commission of ethnological expertise.

Projects for the construction of large industrial facilities that will be located within the territories of traditional nature management of different natural and economic zones.

1. Operation of the Vostochny cosmodrome: "Fall area No. 985 of the central block and tail section flaps of the III stage of the Soyuz 2 ILV, stages 1a and 1b" and the Fall area "983 of the head fairing of the Soyuz 2 ILV, stages 1a and 1b". 
The operation of the Vostochny cosmodrome will include territories of traditional nature management of six administrative districts within four natural and economic zones:

o Southern mountain-taiga agriculture, hunting and reindeer herding-Aldansky region;

o South-Western middle taiga reindeer-farming-cattle breeding-Olekminsky region;

o North-West northern taiga hunting and reindeer breeding-Zhigansky, Oleneksky regions;

o Western middle taiga horse breeding and cattle breeding with the development of the diamond industry—Verkhnevilyuisky, Vilyuisky districts.

The project received a positive conclusion of the ethnological expertise by the order of the Government of the Republic of Sakha (Yakutia) dated 12 February 2016, No. 111-r.

2. Main gas pipeline "Power of Siberia". Stage 2.1-2.8.

The construction of the main gas pipeline at stage 2.1-2.18 will include three administrative districts within the territories of traditional nature management of two natural and economic zones:

1. Southern mountain-taiga agricultural-hunting-reindeer-breeding-Aldan, Neryungri regions;

2. Southwest middle taiga reindeer-farming-cattle-breeding-Olekminsky district.

The project received a positive conclusion of the ethnological examination by the order of the Government of the Republic of Sakha (Yakutia) dated November 12, 2019 No. 1458-r.

\section{Conclusions}

In accordance with this goal, the assessment of the current state of life of the indigenous peoples of the Republic of Sakha (Yakutia) has been carried out, and projects for the industrial development of territories of the traditional nature management in natural and economic zones have been analyzed. On the territory of the republic, eight natural and economic zones have been identified for background (agricultural) industries, taking into account the controlling factor-the vulnerability of natural landscapes to technogenic impacts. As the Development Strategy of the Republic of Sakha (Yakutia) for 2030 with a vision for 2050 shows, like the previous strategies, the mining industry remains the basic sector of the republic's development. At the same time, economic growth is ensured through the consumption of natural resources, primarily minerals. At the territories of the traditional nature management of the republic in the near future, 15 investment projects are planned, which is associated with new threats and risks to the life of the population. The largest number of projects is provided for southern part of Yakutia (seven projects), as well as the Arctic and northern territories (six projects). The development strategy of indigenous peoples should be aimed at preserving the traditional types of nature management and traditional culture of the indigenous peoples, introducing mutually beneficial cooperation between business and indigenous peoples, the regulation tool of which should be ethnological expertise.

\section{Findings}

1. The number of indigenous minorities in Yakutia, according to the 2010 census, is $39,936(4.2 \%$ of the total population of the republic), which is 36,079 people-Evenks and Evens. The number of indigenous peoples in 2010 increased by 2.4. times compared to 1970.

2. The indigenous population of Yakutia (Evenks, Evens and Yakuts), according to the paternal and maternal lines, as well as some autosomal loci, is characterized by low genetic diversity compared to other East Eurasian populations, which can lead to negative consequences in relation to their health when exposed to technogenic pollution.

3. The planned increasing industrial development of the territory of the republic may cause large-scale disturbances of the earth's surface, depletion of biological resources and pollution of the environment, which will ultimately lead to a deterioration in the quality of life of the population. 
4. When implementing new projects at the territories of traditional nature management, it is necessary to conclude a tripartite agreement on cooperation and financing of specific programs between industrial companies, government bodies of the Republic of Sakha (Yakutia) and authorized representatives of indigenous minorities.

Author Contributions: Conceptualization: E.B. and A.S.; Formal analysis: A.B., A.F. and G.D.; Funding acquisition: E.B. and A.S.; Methodology: E.B. and A.S.; Writing original draft: E.B. and A.B.; Writing review and editing: E.B. and A.S. All authors have read and agreed to the published version of the manuscript.

Funding: This research was funded by grants from the Russian Foundation for Basic Research (No. 20-010-00252_A and No. 18-05-60035_Arktica).

Conflicts of Interest: The authors declare no conflict of interest.

\section{References}

1. Fedorova, E.N. Population of Yakutia: Past and Present (Geodemographic Research), 2nd ed.; rev. and add; Science, Sib. Enterprise RAS: Novosibirsk, Russia, 1999; p. 207.

2. Filippovich, N. Ya. Pole of Cold. Verkhoyansk Meteorological Station and Its History; Gidrometeoizdat: Leningrad, Russia, 1972; p. 72.

3. Federal Service for Hydrometeorology and Environmental Monitoring (Roshydromet). No. 140-2462. Available online: http://www.meteorf.ru/ (accessed on 22 August 2005).

4. Zhirkov, I.I. Geography of Yakutia; Zhirkov, I.I., Zhirkov, K.I., Maximov, G.N., Krivoshapkin, O.M., Eds.; Publishing house of NKI "Bichik": Yakutsk, Russia, 2004; p. 301.

5. Robbek, V.A.; Vasiliev, Y.T.; Baisheva, S.M.; Donskoy, R.I.; Syrovatsky, D.I.; Tobukov, P.Z.; Sosin, P.V.; Donskoy, F.S.; Popova, A.G.; Romanov, G.I.; et al. Development of Indigenous Small-Numbered Peoples of the North of the Republic of Sakha (Yakutia) until 2020; GU RIMTS: Yakutsk, Russia, 2007; p. 140.

6. Popov, N.I. Charter on the Management of Foreigners. In Questions of Sovereignty in the Republic of Sakha (Yakutia); YaSC SB RAS Publishing House: Yakutsk, Russia, 1996; pp. 27-30.

7. The Law of the Republic of Sakha (Yakutia) on Domestic Reindeer Breeding/Adopted by a Resolution of the House of Representatives of the State Assembly (Il Tumen of the Republic of Sakha (Yakutia) from 25.06.1997 3 N 180-I (as Amended by the Laws of the RS (Y) from 25.04.2006 341 -3 N 697-III, Dated 15.10.2009 736-3 N 363-IV). Available online: http://docs.cntd.ru/document/804912120 (accessed on 27 June 2020).

8. Donskoy, F.S.; Robbek, V.A. Indigenous Minorities of the North, Siberia and the Far East at the Turn of the XX-XXI Centuries: A Brief Overview; IPMNS SB RAS Publishing House: Yakutsk, Russia, 1997.

9. Poiseev, I.I. Sustainable Development of the North: Environmental and Economic Aspect; Siberian Publishing Company RAS: Novosibirsk, Russia, 1999; p. 280.

10. Popov, Y.V.; Kostyuk, V.G.; Tugunzhekova, V.N. Ethnic Groups of Siberia in the Context of Modern Reforms (Sociological Expertise); Publishing house "Nonparelle": Novosibirsk, Russia, 2003; pp. 90-92.

11. Ignatieva, V.B.; Abramova, S.V.; Pavlov, A.A.; Vinokurova, L.I.; Argunova, T.V.; Vasiliev, V.E.; Vasilieva, R.I. Ethnosocial Development of the Republic of Sakha (Yakutia): Potential, Trends, Perspective; Science: Novosibirsk, Russia, 2000.

12. Robbek, V.A.; Kostyuk, V.G.; Baisheva, S.M. The Attitude of the Peoples of the North to Market Transformations // Humanities in Siberia; Publishing House of the Siberian Branch of the RAS: Novosibirsk, Russia, 2006; pp. 82-87.

13. Krivoshapkin, V.G.; Protopopova, R.N. Medical and Social Problems of the Indigenous Small-Numbered Peoples of the North in the Transition Period. // Indigenous Small-Numbered Peoples of the North, Siberia and the Far East of the Russian Federation in the Context of Modernization of Society/Scientific and Practical conf., Dedicated to the Decade of the International Indigenous Peoples of the World in Yakutsk, Russia; Science: Novosibirsk, Russia, 2004; pp. 35-42.

14. Bogoslovskaya, L.S. Indigenous Peoples of the Russian North in the Context of Global CLimatic Changes and the Impact of Industrial Development; Library of the Indigenous Peoples of the North: Moscow, Russia, 2015; Volume 16, p. 134.

15. Burtseva, E.I.; Petrova, E.I. Environmental problems of the northern territories of Yakutia in the context of industrial development and global warming. Successes Mod. Nat. Sci. 2017, 5, 83-88. 
16. Sleptsov, A.N. Ethnological expertise in places of traditional residence and traditional economic activity of the peoples of the north: Regional experience of legal regulation and law enforcement practice. Eurasian Law J. 2013, 12, 71-75.

17. Sleptsov, A.N. Regional aspects of the development of the Russian Arctic. Arct. North. 2015, 19, 115-133. [CrossRef]

18. Sleptsov, A.N. Ethological Expertise in Yakutia: Regional Experience of Legal Regulation and Enforcement. North. Rev. 2015, 39, 31-38.

19. Burtseva, E.I. Compensation of losses caused to associations of indigenous peoples in the conditions of industrial development of territories. Econ. Nat. Manag. 2018, 2, 23-38.

20. Sannikova, Y.M.; Boyakova, S.I.; Filippova, V.V. Ethnological expertise in the Republic of Sakha (Yakutia): Guidelines for field research/Arctic and North in Modern Humanitarian Research; [Electronic resource]: Collection of Scientific, Article; Publishing House IGiPMNS SB RAS: Yakutsk, Russia, 2018; pp. 52-62.

21. Velichenko, V.V. Features of Assessing Damage to the Indigenous Small-Numbered Peoples of the North from the Loss of a Part of Hunting Resources. Humanities, Social-Economic and Social Sciences; National Scientific Journal: Krasnodar, Russia, 2017; Volume 12.

22. Velichenko, V.V.; Sleptsov, A.N. Protection of Traditional Crafts of Indigenous Peoples of the North: Socio-Economic Aspects and Methodology; Amazonia Investiga: Florencia, DC, USA, 2018; Volume 7, pp. 165-177.

23. Potravny, I.M.; Popova, I.M.; Melnikova, D.M. Investigation of the natural and ethnological component in the substantiation of projects for the industrial development of territories of traditional nature management. Horiz. Econ. 2016, 6, 25-30.

24. Shadrin, V.I. Ethnological expertise as a tool for the protection of the indigenous peoples of the North. Experience, problems and prospects (on the example of the Republic of Sakha (Yakutia). In Proceedings of the International Research and Practice-Oriented Conference, 380th anniversary of the accession of Yakutia to the Russian state, Saint Petersburg, Russia, 28-30 November 2013; pp. 406-413.

25. Potravny, I.M.; Gassiy, V.V.; Chernogradsky, V.N.; Postnikov, A.V. Social responsibility of subsoil users in the territory of traditional nature management as the basis for partnership between government, business and indigenous peoples. Arct. Ecol. Econ. 2016, 2, 5663.

26. Potravny, I.M.; Gassiy, V.V.; Afanasyev, S.M. Territories of traditional nature management: Development constraints or economic growth factors? Arct. Ecol. Econ. 2017, 2, 4-16.

27. Sleptsov, A.; Petrova, A. Ethnological Expertise in Yakutia: The Local Experience of Assessing the Impact of Industrial Activities on the Northern Indigenous Peoples. Resources 2019, 8, 123. [CrossRef]

28. Gassiy, V.V.; Popova, I.M.; Potravny, I.M. Assessment of Damage to Indigenous Peoples of the North in Environmental Management in the Arctic Zone. Natural Resources and Integrated Development of Coastal Areas of the Arctic Zone; Sat. Scientific Papers; Federal Research Center for the Comprehensive Study of the Arctic: Arkhangelsk, Russia, 2016; pp. 103-108.

29. Gavrilyeva, T.N.; Mostakhova, T.S.; Boyakova, S.I.; Yakovleva, N.P.; Bochoeva, R.I. Compensation of damage to indigenous peoples of Yakutia from the industrial development of the territory. All Russ. Sci. J. Reg. Econ. Sociol. 2018, 3, 234-247.

30. Burtseva, E.I.; Bysyina, A.N. Damage Compensation for Indigenous Peoples in the Conditions of Industrial Development of Territories on the Example of the Arctic Zone of the Sakha Republic. Resources 2019, 8, 14.

31. Burtseva, E.I. Problems of social protection of the indigenous small-numbered peoples of the North and the industrial development of the Republic of Sakha (Yakutia). In Proceedings of the Resource Economy in the Context of Modern Trends of Globalization, Yakutsk, Russia, 19 March 2015; pp. 186-189.

32. Kaduk, E.V. Traditional environmental management in the Anabar ulus of the Republic of Sakha (Yakutia) in the context of market interaction. Ethnogr Rev. 2017, 6, 111-127.

33. Samsonova, I.V.; Malysheva, M.S. Features of the development of northern domestic reindeer breeding. Eur. J. Soc. Sci. 2018, 4, 116-125.

34. Burtseva, E.I.; Potravny, I.M.; Gassiy, V.V.; Sleptsov, A.N.; Velichenko, V.V. Issues of assessing compensation for losses to indigenous peoples in the context of industrial development of the Arctic. Arct. Ecol. Econ. 2019, 1, 27-40.

35. Burtseva, E.I.; Potravny, I.M.; Gassiy, V.V.; Bysyina, A.N.; Velichenko, V.V.; Volpert, Y.L.; Pavlova, M.B.; Potravnaya, E.V.; Sleptsov, A.N. The Economy of Traditional Nature Management: Interaction of Indigenous Peoples of the North and Business in the Russian Arctic; Economics: Moscow, Russia, 2019; p. 318. 
36. Fondahl, G.; Espiritu, A.; Ivanova, A. Russia's arctic regions and policies. In The Palgrave Handbook on Arctic Policy; Coates, K., Holroyd, C., Eds.; Palgrave: Basingstoke, UK, 2020; p. 195216.

37. Stammler, F.; Ivanova, A. Determining the encounter between industry, local land users and the state on the example of Kamchatka and Yakutia. ARCTIC. XXI Century. Humanit. Sci. 2015, 3, 44-52.

38. Wilson, G.; Fondahl, G.; Hansen, K.G. Governance for arctic sustainability. In Arctic Sustainability, Key Methodologies and Knowledge Domains. A Synthesis of Knowledge 1; Graybill, J.K., Petrov, A.N., Eds.; Routledge: London, UK, 2020; p. 22.

39. Xanthaki, A. Indigenous rights in the Russian Federation: The case of numerically small peoples of the Russian North, Siberia and the Far East. Hum. Rights Q. 2004, 26, 74-105. [CrossRef]

40. Balzer, M. Indigeneity, land and activism in Siberia. In Land, Indigenous People and Conflict; Tidwell, A.C., Zellen, B.X., Eds.; Routledge: London, UK, 2016; pp. 9-27.

41. Daes, E.-I. Prevention of Discrimination and Protection of Indigenous Minorities. Indigenous Peoples and Their Relationship to Land. Final working paper prepared by the Special Rapporteur, UN Commission On Human Rights, Sub-commission on the Promotion and Protection of Human Rights, 53rd Session, E/CN.4/Sub.2/2001.21. 11 June 2001. Available online: https://www.un.org/development/desa/indigenouspeoples/wp-content/uploads/ sites/19/2017/12/IPRelationshipToLand.pdf (accessed on 20 July 2020).

42. Bogoyavlenskiy, D.D.; Martynova, E.P.; Murashko, O.A.; Khmeleva, E.N.; Yakel, Y.Y.; Yakovleva, O.A. Experience in Conducting Ethnological Expertise. Assessment of the Potential Impact of the Gazprom Program of Exploration and Prospecting in the Waters of the Obskaya and Tazovskaya Bays on the Components of Sustainable Development of Ethnic Groups of the Indigenous Peoples of the North; Publishing house "Radunitsa": Moscow, Russia, 2002; p. 132.

43. The Law of the Republic of Sakha (Yakutia) "On ethnological expertise in places of traditional residence and traditional economic activity of the indigenous peoples of the North of the Republic of Sakha (Yakutia)" dated 04/14/2010 820-3 No. 537-IV. Available online: http://docs.cntd.ru/document/895252453 (accessed on 27 June 2020).

44. Scheme for the integrated development of productive forces, transport and energy in the Republic of Sakha (Yakutia) until 2020, approved by the Resolution of the Government of the Republic of Sakha (Yakutia) dated 06.09.2006 No. 411. Available online: http://docs.cntd.ru/document/445038027 (accessed on 27 June 2020).

45. Strategy of socio-economic development of the Republic of Sakha (Yakutia) until 2030 with the definition of a target vision until 2050 (draft). Available online: http://docplayer.ru/76306420-Strategiya-socialnoekonomicheskogo-razvitiya-respubliki-saha-yakutiya-do-2030-goda-s-opredeleniem-celevogo-videniyado-2050-goda-proekt.html (accessed on 10 August 2020).

46. Integrated development of South Yakutia. Investment project / approved by Order of the Government of the Russian Federation No. 302 dated March 10, 2009. Available online: http://www.roszeldor.ru/in_pr_yakutia (accessed on 27 June 2020).

47. Vanderlinden, J. Returning to Legal Pluralism: Twenty Years Later. J. Leg. Plur. Infirm. Law 1989, 149-157.

48. Moor, S.F. Law and social change: The semi-autonomous social field as an appropriate subject of study. Law Soc. Rev. 1973, 7, 719-746. [CrossRef]

49. Griffiths, J. What is legal pluralism? J. Leg. Plur. 1986, 24, 3. [CrossRef]

50. Geertz, K. Interpretation of Cultures; ROSSPEN: Moscow, Russia, 2004; p. 11.

51. Barth, F. (Ed.) Ethnic Groups and Social Boundaries: The Social Organization of Cultural Differences; New publishing house: Moscow, Russia, 2006.

52. Mints, A.A. Issues of a comprehensive economic assessment of natural conditions and natural resources in the light of the problems of modern geography. Izv. Acad. Sci. of the USSR. Ser. geogr. 1965, 2, 65-76.

53. Mukhina, L.I. Questions of the methodology for assessing natural complexes. Izv. Acad. Sci. USSR. Ser. Geogr. 1970, 6, 141-149.

54. Pokshishevsky, V.V. Population and Geography; Publishing house "Mysl”: Moscow, Russia, 1978; p. 315.

55. Nazarevsky, O.R. Map of the Living Conditions of the Population of the USSR; GUGK: Moscow, Russia, 1985.

56. Hamelin, L.E. Canadian Nordicity. It's your North, too; Harvest House (Montreal): Montreal, QC, Canada, $1979 ;$ p. 373.

57. Burtseva, E.I. Geoecological Aspects of the Development of Yakutia; Science: Novosibirsk, Russia, 2006; 270p. 
58. Methodology for calculating the amount of losses caused to associations of indigenous small-numbered peoples of the North, Siberia and the Far East of the Russian Federation as a result of economic and other activities in places of traditional residence and traditional economic activity of the indigenous peoples of the Russian Federation.cology economy Approved by the Order of the Ministry of Regional Development of the Russian Federation dated 09.12.2009, No. 565. Available online: http://docs.cntd.ru/document/902193558 (accessed on 27 June 2020).

59. Resolution of the Government of the Republic of Sakha (Yakutia) On the comprehensive program of the Republic of Sakha (Yakutia) "Social and economic development of the Arctic and northern regions of the Republic of Sakha (Yakutia) for 2014-2017 and for the period until 2020". Dated August 15, 2014 No. 251 (as amended by the resolution of the Government of the Republic of Sakha (Yakutia dated January 25, 2016 No. 12). Available online: http://docs.cntd.ru/document/432880477 (accessed on 27 June 2020).

60. Tarskaia, L.; Zinchenko, R.; Elchinova, G.; Egorova, A.; Korotov, M.; Basova, E. The structure and diversity of hereditary pathology in Sakha Republic (Yakutia). Russ. J. Genet. 2004, 40, 1264-1272. [CrossRef]

61. Tarskaya, L.; Melton, F. Comparative analysis of mitochondrial DNA of Yakuts and other Mongoloid populations. Genetics 2006, 12, 1703-1711.

62. Tugolukov, V.A. Evens//Ethnic History of the Peoples of the North; Science: Moscow, Russia, 1982; pp. $155-168$.

63. Fedorova, S.; Reidla, M.; Metspalu, E.; Metspalu, M.; Rootsi, S.; Tambets, K.; Trofimova, N.; Zhadanov, S.; Kashani, B.; Olivieri, A.; et al. Autosomal and uniparental portraits of the native populations of Sakha (Yakutia): Implications for the peopling of Northeast Eurasia. BMC Evol. Biol. 2013, 13. [CrossRef] [PubMed]

64. Runova, T.G.; Volkova, I.N.; Nefedova, T.G. Territorial Organization of Nature Management; Nauka: Moscow, Russia, 1993; p. 208.

65. The Law of the Republic of Sakha (Yakutia) “On the territories of traditional nature management and traditional economic activities of the indigenous small-numbered peoples of the North of the Republic of Sakha (Yakutia)". (Adopted by a resolution of the State. Meeting (IL Tumen) of the Republic of Sakha (Yakutia) dated 13.07.2005 3 No. 756-III). Available online: http://docs.cntd.ru/document/802070067 (accessed on 27 June 2020).

66. Federal law "On guarantees of the rights of the indigenous peoples of the Russian Federation". (Adopted by the State. Duma on 04.16.1999 approved on 04.22.1999 as amended by Federal Law of 27.06.2018 N 164-FZ). Available online: http://docs.cntd.ru/document/901732262 (accessed on 27 June 2020).

67. Tulaeva, S.; Tysyachnyouk, M. Between Oil and Reindeer: Benefit Sharing Agreements between Oil Companies and Indigenous People in Russian Arctic and Subarctic Regions. J. Econ. Sociol. 2017, 18, 70-96. [CrossRef]

68. Tysiachnyouk, M.; Petrov, A. Benefit sharing in the Arctic energy sector: Perspectives on corporate policies and practices in Northern Russia and Alaska. Energy Res. Soc. Sci. 2018, 39, 29-34. [CrossRef]

69. Tysiachniouk, M.; Petrov, A.; Kuklina, V.; Krasnoshtanova, N. Between Soviet Legacy and Corporate Social Responsibility: Emerging Benefit Sharing Frameworks in the Irkutsk Oil Region, Russia, Sustainability. Sustainability 2018, 10, 3334. [CrossRef]

70. Borisov, E.A. On the strategy of socio-economic development of the Republic of Sakha (Yakutia) until 2030 with the definition of a target vision until 2050. Econ. East Russ. 2017, 1, 5-11.

71. Savvinov, D.D.; Krivoshapkin, V.G.; Tyaptirgyanov, M.M. Ecology of the Vilyui River; YSC SB RAS: Yakutsk, Russia, 1993; p. 238.

72. Pozdnyakov, A.I.; Vol'pert, Y.L. Analysis of the impact of the diamond mining industry on the environment of North-West Yakutia. Probl. Reg. Ecol. 2008, 2, 24-28.

(C) 2020 by the authors. Licensee MDPI, Basel, Switzerland. This article is an open access article distributed under the terms and conditions of the Creative Commons Attribution (CC BY) license (http://creativecommons.org/licenses/by/4.0/). 